\begin{tabular}{l} 
RCCS \\
\hline Annual Review
\end{tabular}

RCCS Annual Review

A selection from the Portuguese journal Revista Crítica de Ciências Sociais

$\# 0$ | 2009

Issue no. 0

\title{
On the Question of Aufhebung: Baudelaire, Bataille and Sartre
}

\section{Françoise Meltzer}

\section{OpenEdition \\ Journals}

\section{Electronic version}

URL: http://journals.openedition.org/rccsar/331

DOI: $10.4000 /$ rccsar.331

ISSN: 1647-3175

\section{Publisher}

Centro de Estudos Sociais da Universidade de Coimbra

\section{ELECTRONIC REFERENCE}

Françoise Meltzer, " On the Question of Aufhebung: Baudelaire, Bataille and Sartre », RCCS Annual Review [Online], \#0 | 2009, Online since 01 September 2009, connection on 30 April 2019. URL : http://journals.openedition.org/rccsar/331 ; DOI : 10.4000/rccsar.331 


\section{Françoise Meltzer}

The University of Chicago, USA

\section{On the Question of Aufhebung: Baudelaire, Bataille and Sartre*}

This essay looks at Sartre's rather nasty 1943 essay on Bataille, "Un nouveau mystique," and the further argument between the two writers on Baudelaire. Sartre accuses Bataille, in the latter's Inner Experience, of introducing the "transcendent into the immanent"; of externalizing the ego, such that human responsibility is elided; of leading, with its fascination with ritual, sacrifice and community, to totalitarianism; of swallowing up history. Sartre uses Hegel's concept of Aufhebung from the Phenomenology as the focus of his critique: Bataille, Sartre argues, removes synthesis from Hegel's trinity of thesis/antithesis/synthesis (Aufhebung) and puts tragedy in the place of the dialectic. This argument about the role of Aufhebung and the dialectic thus raises all the issues fundamental to what was to be called postmodernism: the role and sovereignty of subjectivity, the possibility of the sacred, the use of language, human freedom, the role of history in textual production, the individual as against the community, and the reasons for rejecting the possibility of a transcendental.

Keywords: Aufhebung; Modernity; Postmodernity; Hegel; Baudelaire; Sartre; Bataille.

For Ziva Ben-Porat

One of the major symptoms of modernity and what for lack of a better term we call "postmodernity" seems to be a rapt concern with notions of the dialectic. ${ }^{1}$ Left far behind is the usual triad of thesis-antithesis-synthesis. Hegel, of course, is largely to be thanked for confusing things. In his Phenomenology, Hegel leaves things very murky by continually postponing synthesis (with the promise of eventual Geist, or spirit) and instead using the infamous term Aufhebung. From the German verb aufheben, the noun means to preserve or lift up. Thus the dialectic in Hegel is not synthesized, but continually lifted up to a new series of conflicting forces or antinomies. There lurks here a potential promise of sorts: preserving and lifting up a given dialectic into a new one belies a teleology of transcendence. Indeed, such a goal is explicit with Hegel's Geist. The problem is, of course, that the dialectic becomes crucial for the likes of Marx, Feuerbach, Adorno, Benjamin and so on, where transcendence is at least overtly rejected. What is the implication of Aufhebung in such a context? Why does it become an issue in certain late modern/early postmodern texts?

\footnotetext{
*Article published in RCCS 75 (October 2006).

${ }^{1}$ Versions of this essay have been presented in Portugal at the Universities of Coimbra, Lisbon and Porto. This essay has benefited enormously from the discussions that ensued. I wish to express here my gratitude to my generous hosts at all three institutions, and to thank as well the students who attended the lectures.
} 
There is a remainder of sorts about the Aufhebung - something that needs closer examination. The Aufhebung, for example, is rejected by both Jean-Paul Sartre and his contemporary, Georges Bataille, but for very different reasons. Indeed, a close look at the argument between the two puts the Aufhebung at the center of the discordance. What is at stake, given what Aufhebung seems to promise, is the idea and place of transcendence. Such a notion is rejected by both Bataille and Sartre, at least on the face of it. Sartre because he is a Marxist and existentialist for whom transcendence smacks of religion. Bataille because life must be faced in the horror of the void.

Bataille decides that in one important respect, he is like Baudelaire. Bataille believes that, like the poet, he wants what is understood as impossible: that is, he seeks a simultaneity of contrary experiences - hama, as Derrida reminds us that Aristotle puts it in the Anaximander Fragment. The 'now,' as Derrida continues to note in the voice of Aristotle, cannot coexist with another now. And yet this impossible "co-maintenance of several present nows" (Derrida, 1982: 55) is what Baudelaire can be said to experience, and Bataille can certainly be said to seek. Baudelaire and Bataille will formulate antinomies whose co-existence is by definition impossible and yet irrevocable. They want the antinomies of the dialectic endlessly at discordance. Such a problem of logic is what Derrida (again) will call, with respect to Bataille, a "Hegelianism without reserve." Bataille, Derrida maintains in that essay, is not undergoing "inner experience" (a reference to Bataille's book of the same title) at all, but rather "the "impossible" which is a "torment." There is no interior for the subject in Bataille, Derrida continues, because there is no presence, only an impossible. And there is for Bataille no exterior, Derrida continues, except "in the modes of non-relation, secrecy and rupture" (Derrida, 1978: 272). ${ }^{2}$

The attempt to maintain two nows is an impossible possibility whose name, says Derrida, is time. Such a gesture is what largely characterizes Bataille's project, and what often motivates Baudelaire's as well. In both, the historical situation motivates a willed crisis - a rupture - and that crisis is evident in the impossible logic of antimony, or of two simultaneous "nows." Bataille's antimonies continue and exceed (in the disturbing sense of the term) Baudelaire's. Sartre of course, lives in the same historical upheaval as Bataille; but

\footnotetext{
${ }^{2}$ See also Martin Jay's reading (2005: 366-381 ff), and particularly his discussion of the notion of experience in Bataille.
} 
Sartre refuses to enter into the double vision of Baudelaire, or to give credence to Bataille's economy of excess.

The triangulation Baudelaire-Sartre-Bataille, and the disagreements that ensue between the latter two provide, as I have noted, an opportunity for getting at a significant divergence in modernity, a divergence which begins with the Aufhebung and the role of antinomies. More importantly, however, this divergence marks not only differing notions of transcendence, history, the dialectic and so on. The deviation of opinion between Sartre and Bataille on these issues signals, I will argue, the place where postmodernity begins and takes leave of any modernist, contemporary thought (like Sartre's) that refuses to follow.

\section{Baudelaire}

Baudelaire lives in a singular situation. The first modern poet to read the city as text, he inhabits the urban life in the time of high capitalism. The crowds of the city suddenly have a goal (to and from work; what the French call boulot-métro-dodo); Baudelaire as flâneur does not. He stands, in more ways than one, willfully outside the crowd, moving in nonchalant patterns (as against the goal-oriented flow of the crowd), enjoying an anonymity and isolation from the masses. In his essay "Les Foules," (echoing Poe's "The Man of the Crowd" which Baudelaire had just translated), he writes, "Multitude, solitude: equal and convertible terms for the active and productive poet" (1968: 243). Equal and convertible terms indeed, opposites though they may be.

There are times when Baudelaire revels in such opposites, and plays lustily with what for other mere mortals is open contradiction. "Les Foules" is one such text. Other texts, however, such as "I'Horloge," rail against the contradiction of time, for example, in a manner that insists on its antinomies: time crushes by going slowly: three thousand six hundred times an hour, the second whispers, "Remember." "Je suis Autrefois" says the clock, and adds "Remember" again in English, French and Spanish (its metal throat, says the poet, speaks all languages). Remember, the poet adds, because "the abyss is always thirsty" and "it is too late" (ibid.: 76-77). Both realizations - the hideous slowness of time and, conversely, time's gone-in-a-flash quality - exist simultaneously for the poet; two "nows." The very impossibility of their co-existence makes for the horror of time, and the force of the poem. (We remember Derrida's point that to attempt maintaining two nows is an impossible

\footnotetext{
${ }^{3}$ This and all other translations from Baudelaire are mine.
} 
possibility whose name is time). In his Journaux intimes Baudelaire writes, "At every moment we are crushed by the idea and sensation of time." And he adds, creating another opposition, "There are only two ways of escaping from this nightmare - in order to forget it: pleasure and work. Pleasure exhausts us. Work strengthens us. Let us choose" (ibid.: 1266).

The problem, however, as the life and texts of Baudelaire attest, is that the presence of two terms preclude choice. They are always, irrevocably, there. Or there is a choice which, as Georges Bataille makes clear, merely reinforces its opposite without annihilating the first term. There is an opposition in favor of Good, notes Bataille reading the poet, but it is an impossible resolution. He adds that Baudelaire chose God as he did Work, in a completely nominal way, "in order to belong to Satan." Baudelaire could not decide, Bataille continues, "whether the opposition was his own, within himself (between pleasure and work) or external (between God and the devil)." "As a child I felt in my heart two contradictory feelings," writes Baudelaire in a passage that Bataille will cite, "the horror of life," Baudelaire continues, "and the ecstasy of life" (Bataille, 1957: 42). And there is Baudelaire's famous remark that man, at all times and at every moment is possessed by two simultaneous postulations: one toward God, the other toward Satan. Bataille traces a triple series of antinomies here: between pleasure and work; between the Good and Satan; and a third coupling that encompasses the other two: the inner (work/pleasure) versus the outer (God/Satan). Baudelaire, Bataille tells us, is even unable to discern what is inner and what outer.

It is not by accident that Bataille focuses on this particular problem in Baudelaire given that it is a problem he shares with the poet; indeed a problem in which Bataille will exceed Baudelaire. But let us look now to another point Bataille makes (which prepares the argument with Sartre): Baudelaire, writes Bataille, is living the relationship between production and expenditure in history. Baudelaire's experience is in history, not individual (Bataille, 1957: 42). The unparalleled tension which I have noted in the poet's work, and which Sartre comments on in his own reading, is for Bataille the result of "a material tension imposed historically, from without." If Derrida is right, that there is no interior for the subject in Bataille except as non-relation, secrecy and rupture - then this might explain why Bataille reads opposition in Baudelaire as imposed by history, from without. But this cannot, as we see, be a complete explanation. For Bataille is clear that Baudelaire's problem is a society caught in a material tension of history. That society, like the individual, is forced to choose between the concerns for the future and the present instant. Bataille, having first 
noted that Baudelaire does not know the difference between inner and outer in this context, decides that the poet does not realize that it is history that is pressing in upon him from the outside. The society around Les fleurs du mal is claiming success and satisfaction as the primary goals; capitalism is its credo.

Baudelaire, however, is clearly dissatisfied with satisfaction. ${ }^{4}$ For to be useful is disgusting for Baudelaire, because it is the heart of the bourgeois ethos. ${ }^{5}$ Sartre notes complacently that to choose Evil is to uphold Good. Bataille complicates this approach: for Baudelaire, denial of the Good is, in Bataille's words, a denial of the future and therefore anti-capitalism. The poet's scorn for utilitarianism is a syllogism of sorts: to be useful is to be a good bourgeois who turns his back on the horrors of history (perpetrated by his own class) for the sake of a future dedicated to increasing wealth. Therefore, to refuse the Good in this sense, and to refuse the future, is to repudiate bourgeois morality and its hypocrisy. Evil becomes a better Good.

The failed revolution of 1848 did much to create the irremediable presence of an impossible series of antimonies for Baudelaire. And Barthes (in Writing Degree Zero) is right that the tenses chosen by fiction writers after ' 48 betray, not only social class, but the relation to history as well. Because if ' 48 did nothing else, it increased the exfoliation of class begun by the "real" revolution of 1789. It is this new society that Baudelaire had wanted to help shatter; ' 48 built a new world on the foundations of a complete bourgeois triumph, producing an anathema: a republic based (as Georges Sand was to put it) on the suppression and murder of the working class. The self-satisfaction of that class in the wake of ' 48 is thus unacceptable for ethical thinkers. Many writers of the period refuse, in other words, to forget. Bourgeois society, writes Bataille, introduces a fundamental change. And he adds, "From Charles Baudelaire's birth to his death," Europe undergoes a metamorphosis long in preparation. The civilized world is now founded "on the primacy of the morrow, that is on capitalist accumulation" (Bataille, 1957: 44). For those who, like Baudelaire, do not wish to follow, apathy, passivity and disillusionment (as Lukacs has amply pointed out) seem the inevitable choices.

Baudelaire's poetry posits antinomies not only for compelling personal, biographical reasons, then. The clashing of opposites in his work, the unredeemable (his word)

\footnotetext{
${ }^{4}$ Sartre, 1946. For a full discussion of this argument between Sartre and Bataille, seeMeltzer, 2002: 63-6 ff.

${ }^{5}$ For a useful study of the complex class delineations in nineteenth-century France, see Jan Goldstein, 2005.
} 
contradictions that risk explosion at any moment, are (to return to Bataille's words), history pressing in. But where is in? The doubleness which Baudelaire traces in so many of his poems seems to trace as well the emptying out of subjectivity in the face of industrialization. "Emptying out" such that it is no longer clear where "out" is emptying from. In much of the poetry of Baudelaire, we see "up" and "down" replacing inside and outside. Subjectivity, in other words - at least the subject as he understood himself before revolution - has become a concept all unclear.

The encounter itself in Baudelaire suffers from antinomy - whether it be that with the poor (where the gaze dominates), with beauty (as in "Harmonie du soir"), with the past ("Andromaque, je pense à vous"); with places dreamed of but never attained ("L'invitation au voyage"); even with the divine, as in "Correspondances," where ritual is reinscribed but the accent is on loss. And then there are, as I have noted, the eternal above and the endless below. So, for example, the world is a dictionary of hieroglyphics mirroring the higher realm, but we cannot read the dictionary. The "joy of descent," as Baudelaire puts it, leads to the gouffre (the abyss), le néant (nothingness), le vide (emptiness) - a terrifying vide of bottomless promise.

The point here is not to enter into the infamous binaries that have so motivated deconstructive and other critical theories in the last decades - binaries which, as Levinas has often noted, lead only to changing positions and collapsing the same into the same. On the contrary: my point is to affirm that Baudelaire's oppositions are irredeemable because this is his way of experiencing modernity and its Weltsraum. The strident tension, the mental anguish and cacophony which the presence of two opposing "now's" cause the poet, are frequently described and experienced by him as a need for rupture. "Anywhere out of the world," he pleads in an English title. "I will accept even death if it is something at least new," he writes in a prose poem.

If for Walter Benjamin, the Fleurs du mal registers a breakdown, the loss of aura and the ensuing shock, for Baudelaire himself modernity is comprised of the eternal and the fleeting at the same time. One thinks, for example, of the famous poem "A une passante," in which a passing woman in mourning fleetingly meets the poet's gaze (in a moment concretizing epiphany, since it is produced by the illumination of a lightening bolt) (Baudelaire, 1968: 88). It is a busy city street, and she is part of the crowd, he is the observing flâneur. The poem ends, famously, with the words, "O toi que j'eusse aimée, ô toi qui le savais!" An always-too- 
late, because the eternal is never begun, only as if remembered. Halfway between Pascal (with his two infinities) and Kierkegaard (with his notion of trembling), in Baudelaire the poetic subject is overwhelmed by the empty parts of the city under demolition which seem to echo the absence of God, the irrevocability of evil, the resulting failure of encounter.

Contradiction is Baudelaire's duty, and explosive laughter erupts from him, as he puts it, "without a smile." "There is always something which breaks, which destroys itself," he writes in one of his journals. The antinomies are preserved and forced together to the point of atomic fission, for in Baudelaire the contradictions of modernity are inscribed in every conceivable realm: social, political, literary, aesthetic, architectural, personal, philological, technological (the daguerreotype, with its prolonged staring, writes the poet, destroys the gaze); theological (what is original sin if not the proof of man's misery and grandeur for the poet?), ontological - the list is endless. Modernity is precisely the presence of two "now's" at the same time - an impossibility which memory and the present, like the double room, force into an endless palimpsest of recurrence (like the eagle eating Prometheus's liver, which regenerates eternally). Moreover, the co-maintenance of antinomies is what blurs the understanding of where the borders of subjectivity lie for Baudelaire: where is inside and where outside when the very terms co-exist in a constant state of destabilization? What does it mean to turn the subject inside out onto the modern city, a city that is under constant construction? This might be called both the willed project and the tragedy of Baudelaire. It is in this sense that history presses in on him.

The unsatisfactory for Baudelaire is then "agonizingly attractive" - satisfying, in other words. The refusal to work is validated by what both Bataille and Sartre understand as the "transcendence of obligation." But Bataille argues, contra Sartre, that this is not an individual error in Baudelaire. Sartre, writes Bataille, thinks he has successfully condemned Baudelaire, and shown the "puerile" aspect of his attitude (Bataille, 1957: 161). Sartre thinks Baudelaire's problems can be explained by the death of his father when the poet was six; by his mother's remarriage to a man Baudelaire loathed; by the ensuing loss of his adored mother. Sartre's book-long introduction to Baudelaire, Bataille notes tersely, is less the work of a critic than it is that of a "moral judge, to whom it is important to know and affirm that Baudelaire is to be condemned" (ibid.: 163). Baudelaire, Sartre has concluded in his judgment, chose to "exist for himself as he was for others." Baudelaire chooses the notion of his own "nature," and after that gives up liberty. He is therefore, in Sartrean terms, 
inauthentic. It is to be noted here that much of what Sartre finds to condemn in Baudelaire he will also condemn in Bataille.

Bataille retorts with vigor to Sartre's analysis: the unparalleled tension in the poet's work, and "the fullness with which [it] has invaded the modern mind," Bataille writes, cannot be explained by his personal errors, but by "the historically determined expectation to which these errors corresponded" (ibid.: 42). It is not only individual necessity which is expressed in Les fleurs du mal; the poems themselves are also the result, as we have noted, of pressure from without (ibid.: 43). To wit: the poems were written in a society which no longer sustained the primacy of the future in conjunction with a nominal, sacred present (through what Bataille calls festivity: feasts, sacrifices, an immutable notion of the Good). The new society forming in Baudelaire's day is "a capitalist society in full swing," one which chooses the dams of the industrial age over the lakes of Versailles (and similarly has Haussman build boulevards in Paris to insure against the barricades of the future). If the present has no sacred, it is because its only purpose is to pave the way to the future.

There is an irony here, of course. Bataille, the anarchist of sorts, the economist of excess, the theoretician of violence, scholar and self-proclaimed practitioner of sacrifice - Bataille hypostatizes rupture in Baudelaire as caused by a historical situation: capitalist culture destroys the ancien régime's sense of time and memory, and makes productivity its sole virtue. Sartre, the Marxist (still, in this period) who does not believe in the Freudian unconscious, explains Baudelaire on biographical, psychological grounds and condemns him on existential ones.

For Bataille then, it is the tension in French society around 1848 which mirrors the tension within the poet. We can call this an identification of sorts; Bataille will have the same response to the cataclysmic events in his own day. In the wake of such political and social upheaval, where does the "inside" of the subject lie? How can he know? Part of the response, I am arguing, in Baudelaire at least, is to echo the external chaos in a poetry and poetics of antinomy. Here too, Bataille identifies. Indeed, the epigraph for his response to Sartre on Baudelaire makes an ontology of antinomy, as it were, fundamental: "Man cannot love himself completely unless he condemns himself. ${ }^{\prime \prime}$ The definition of man for Sartre is he-who-seeks-liberty in a moral, existential universe; he who is condemned to be free. For Bataille, man is defined by a submission to an interdiction, and the simultaneous insistence

\footnotetext{
6 “L'Homme ne peut s'aimer jusqu'au bout s'il ne se condamne” (Bataille, 1957: 27).
} 
upon transgression. Sartre is "closed to this truth"; Bataille, like Baudelaire, is convinced by it (Bataille, 1957: 161). Already, then, we see the difference between Bataille and Sartre in the notion of morality, of the very definition of the human, and in antimony as the unacceptable (Sartre) and the indispensable (Bataille).

\section{Sartre's experience of Inner Experience}

Sartre reviewed Bataille's Inner Experience in February 1943, in Cahiers du sud. ${ }^{7}$ It is forty-five pages long, which is a rather lengthy manner of calling a book bad. The review has been recently called a "great literary misunderstanding," in the tradition for example of Gide's failure to recognize Proust's genius, or Balzac's misjudgment of Stendhal. ${ }^{8}$ But "great literary misunderstanding" is not quite accurate, for Sartre's review is literary only in its initial concerns, and a misunderstanding only if that term is equated with something like the will-not-to-know (which, it will be remembered, is a notion of Nietzsche's). The debate is first to do with philosophy: with the role of literature in the academy and the ensuing assumptions about knowledge. It is as well, secondly, a flexing of Sartre's position of expertise: "Monsieur Bataille" (as Sartre consistently refers to him) does not understand Jaspers and is confused about Heidegger. He uses ipseity wrong because he reads Heidegger in Corbin's translation. Indeed, Bataille "ne comprend pas la philosophie" (Sartre, 1947: 156). Thirdly, the review is an argument about language. For Sartre language remains an instrument-useful, reliable, cooperative. Alain (philosopher and famed teacher - of Simone Weil, e.g.) - Alain, writes Sartre, is an important contemporary philosopher who "has confidence in words" (ibid.: 148). What is Bataille doing with his "slippery sentences" and mixtures of poetry and prose?

Bataille is the heir of Baudelaire and Mallarmé in that Bataille's texts try to exceed language itself and constantly remark on the irony of using language to describe its ineluctable insufficiency. Sartre, a rationalist in this area, is more baffled than admiring. For

\footnotetext{
${ }^{7}$ The text, "Un nouveau mystique," is reprinted in Jean-Paul Sartre, Situations I (1947).

${ }^{8}$ See, e.g. Heimonet, 1996: 59-73. Caroline Blinder has noted that Sartre's critique of Bataille in question here "paradoxically repeats and redefines itself in Bataille's 'La Morale de Miller"” (Blinder, unpublished ms.). Bataille was a member of Henry Miller's "Defense Committee," fighting to protect Miller from the legal action threatened in 1946 by Daniel Parker, the self-proclaimed President of the "Cartel d'actions socials et morales." Parker wanted to charge Miller with obscenity for Tropic of Cancer, Tropic of Capricorn and Black Spring. Bataille wrote an essay in the first issue of Critique, which he founded, on the "Affaire Miller." Blinder rightly notes that Bataille's essay on Miller is in fact a continuation of his disagreement with Sartre over the role of literature; a disagreement which begins with Sartre's "Un nouveau mystique." See especially Amy Hollywood's excellent discussion of "Un nouveau mystique," in her Sensible Ecstasy (2002: 29-35 ff).
} 
him, as he makes quite clear in "Un nouveau mystique," language is a tool to be honed, to be well-marshaled (adequate, rational, etc.). Though Sartre situates Bataille's work in the tradition of the essay, with Pascal and Montaigne, Bataille's use of language is for Sartre nothing less than a horror: "One guesses," he writes of Bataille's style, "that this plastic, fused matter, with its abrupt solidifications which liquefy as soon as one touches them [...] could not be accommodated to ordinary language." Or: "the style progresses by strangling itself, tying itself into knots" (ibid.: 146). Bataille writes by sacrificing words as bloodily as possible, adds Sartre in some disbelief, and he shares with Camus a hatred of discourse and of language. It is no wonder, then, that Sartre alludes admiringly, and with relief, to Voltaire - the doyen of linguistic clarity and ease.

Fourthly and above all, however, Sartre's review is an attack on Bataille's interest in the sacred. Yes, writes Sartre, Bataille agrees with Nietzsche that God is dead. But not only has Bataille survived the death of God, God himself has somehow survived his own death as well. At least, that is how Sartre sees it. Bataille says he is trying to create a new religion without a god, but Sartre smells a rat: God, as Simone Weil was to put it, is hiding behind the furniture.

This brings us to the notion of the sacred, which lies at the heart of Sartre's problem with Bataille. In his later essay on Manet (1955), Bataille gives his definition of the sacred. It is "that which, being only beyond meaning, is more than meaning." What Bataille sees in Manet's paintings is the "shipwreck of the subject" - that moment when subjectivity is killed (Bataille, 1983: 69). But, as Michel Surya points out in his remarkable biography of Bataille, what interests Bataille is not so much the dead subject as the subject in the process of disappearing. In the words of Surya, the having-been-put-to-death of the subject fascinates Bataille more than its proclaimed death (as that which is finished). Bataille wants a haunting, the liminality of death at its moment of occurrence (Surya, 2002: 471-72). And so Sartre is right: God subsists as a haunting in Bataille. But Bataille wants this haunting, this ghost of death after death itself; Sartre does not, for he sees in it nothing more than the transcendental returned through the back door.

For Bataille, the force of the sacred, the heterogeneous, is fundamental to all social life. The "religious" has been largely forgotten and needs by scientific method (the influence here is of course Durkheim) to be reinstated. For Sartre, this is Bataille's biggest error: to imagine studying an unknowable negativity by means of a scientific method, and in the 
names of Durkheim and Mauss! Durkheim, writes Sartre, is surely rolling over in his grave. And here perhaps we can get at the heart of the matter. Bataille's notion of the sacred is akin to the vanishing of the subject, to the break as he sees it in representation itself, to the absent-presence (as we used to say) of an already-dead God, to that which can bring being beyond meaning and beyond subjectivity. And Sartre? Significantly, when Sartre calls his book Saint Genet, he is doing more than evoking the play "The True Saint Genet" by Rotrou (1646). As there is a sacred for Bataille, there is sainthood for Sartre. But what is meant by "saint" for Sartre is most revealing. Obviously, he cannot mean it in any but an atheistic sense. By "saint," Sartre means that Genet is a pariah, but one who assumes his exclusion; takes a glorious responsibility for it. Genet behaves against the norm and against convention (that world which Sartre calls that of the salauds).

There lurks a double-edged meaning when Sartre refers to Inner Experience as a "martyr essay." On the one hand, he faults Bataille for a style which has yet to find itself but is rife with agony, hideous passion, narrative promiscuity, and a hatred of discourse. "Look at my ulcers and wounds," the essay seems to say. On the other hand, Bataille is in many ways himself a pariah and, like Genet, against bourgeois norm and convention. ${ }^{9}$ Religious terminology multiplies in Sartre's lexicon here. Inner Experience, he notes sardonically, reads like a combination of the Gospels and Baudelaire's "I'Invitation au voyage." A combination, one assumes Sartre means, of conveying "The Truth" and fantasizing about a voyage of exotic/erotic possibilities that will clearly never be undertaken. And so, of course, Bataille is the founder of a new mysticism.

Genet, in contrast, is a "saint" for Sartre: he is the pariah, the one who is excluded by society. We note here the opposing symmetry between Sartre and Bataille (though the latter considered Sartre's Saint Genet his greatest work). For Bataille, the sacred is that which is transubjective, which celebrates in fact the disappearance of the subject in a transcendence of silence, as Sartre calls it. For Sartre on the other hand, sainthood is precisely that singularity which, authentic, assumes responsibility for its own history and at the same time chooses (in this case) crime. It is not because Genet was inevitably led to crime that he chooses a life of crime, notes Sartre: pre-determinism, no matter the cause, erases man's

\footnotetext{
${ }^{9}$ But as Surya and others remind us, Bataille frequently published under pseudonyms and felt that his reputation as an archivist of medieval manuscripts at the Bibliothèque Nationale had to be protected. But there are of course also more metaphysical reasons: Bataille wanted to write in order to erase his name. See Surya, 2002: 88-92.
} 
liberty and his singularity. Meanwhile, it is precisely such "erasure" that Bataille seeks. This is a fundamental difference in the notion of being between the two.

Finally, however, things are even more serious. If Bataille, as Sartre puts it, wants "to exist completely and instantly" (tout entier et tout de suite), it must be because for Bataille there is no possibility (even if there were a point) of choosing, no freedom for creating essence. This is because Bataille is unable to understand that the ego (/e moi) is temporal, that it needs time to realize itself. In vain does Bataille tell us that the ego is in shreds, comprised of instants, writes Sartre. He concludes: "for the time of interior experience is not made up of instants." No doubt Sartre is in part responding to a well-intended footnote by Bataille in his article entitled, as it happens, "The Sacred" (Bataille, 1985). There Bataille writes of Sufi mysticism as describing the dangerous power of instants: they are like swords, cutting at the roots of both the future and past. "the moral character of the sacred is reflected in this violent representation," notes Bataille (ibid.: 245). Having elided mysticism, the sacred and the instant, Bataille then moves to Sartre for his example: La Nausée speaks of the importance of the instant "in a significant way." Sartre cannot have been happy with this interpretation, for it allies him with the erasure of history. (Of course we know that Sartre later rejected much of his own novel...) "Un nouveau mystique" provides Sartre with an occasion to articulate his position with respect to what are for him three areas worthy, at the very least, of extreme suspicion: mysticism, the sacred and the instant. They all smell, of course, of the transcendental.

Sartre's conclusion is as condescending as was the opening of his review: At the outset, he wonders if the whole of Inner Experience is no more than a long commentary on Maurice Blanchot's Thomas l'obscur, as Camus had suggested to Sartre. At the end he decides that Bataille needs serious psychoanalysis - but not, he hastens to add, of the Freudian variety. Despite this dismissive ending, there is a great deal at stake here: Monsieur Bataille, Sartre concludes, introduces the transcendental into the immanent - not a minor point. Two further issues are equally at issue: first, the notion of subjectivity; second, the danger Bataille's universalizing thought poses to historicity. As to the first (the subject), we have noted that for Sartre Bataille's problem is that he understands the ego as an external object, as something that does not belong to the subject. (This is also, one might note, the reproach Sartre makes of the Freudian unconscious). It is worth noting therefore, that we see in Sartre a certain tenacity with respect to the singularity of the individual. As to the second issue, the 
danger of this kind of mystical thinking, Sartre is clear. Bataille's thought is totalitarian because it is not analytic and because it swallows up history. It is inauthentic because it proclaims the death of God but refuses atheism. Most importantly for our purposes here, Bataille (says Sartre) considers man himself an irresolvable contradiction (Sartre, 1947: 154). Bataille thus follows the footsteps of Kierkegaard, Nietzsche and Jaspers in believing that some conflicts cannot be solved. He therefore removes synthesis from the Hegelian trinity, says Sartre, and substitutes tragedy for the dialectic. Why tragedy? Because Bataille wants, in fact, two nows: he "takes upon himself two contradictory points of view simultaneously" (ibid.: 162).

With Bataille, the antinomies move dangerously even closer - indeed, one might say that they are forced into confrontation. In Baudelaire, we see the ecstasy of poetry and the abyss of spleen - a stance which produces, as Jean-Pierre Richard has noted, two abysses (the sky and the depths). These are simultaneous, battling forces in the poet's soul. Whereas Baudelaire vests the clash of antinomies in the poet's psyche, Bataille inscribes contradictory forces on the body. For example, his infamous "pineal eye," the slit on the top of every human's head. This slit is the scopic and mental analog of the anus, and Bataille calls it "the jesuve" (a combination, among other things, of Jesu, Vesuvius, and "Je") (Bataille, 1985: 73-78). It is the manifestation, and not the synthesis, of Bataille's violent antinomies.

The sun - a central image in Bataille - also insists on antinomy. The sun gives light and sight. But the same sun also blinds if looked at directly and destroys life (rotting corpses, notes Bataille). And if Baudelaire is obsessed by the eyes of the poor, their gaze, Bataille is famously obsessed with "the eye" tout court. His blind, syphilitic father clearly inspired the emphasis on the pineal eye, the slit eye, the Story of the Eye, and so on. Yet we need not perform the error on Bataille that he believed Sartre was committing on Baudelaire: like that poet, Bataille's work too is imprinted by the pressure of history and is not purely the result of a single mind and its psychology.

It might be well to recall here that Bataille attended the Kojève seminars on Hegel in the 1930s (and Sartre, unlike most intellectuals of the day, did not). Bataille wrote several essays analyzing the dialectic. Whereas he was strongly Hegelian in 1937, by 1944 he was willfully less so. History, we can agree, intervened. Clearly affected by Kojève's reading, Bataille comes to believe that the Hegelian dialectic begins with the struggle for recognition, and remains too much within it. What becomes an issue for Bataille is the status of negativity 
within the dialectic. What can be the recognition of negativity, when radical otherness is continually elided? As Bataille, puts it, Minerva's owl arrives when night has fallen; so too, the philosopher always arrives when it is too late.

Like Baudelaire, then, for Bataille it is always already too late. It is as if the political and conceptual upheaval that is modernity, with its wars of technology, have produced an always already which is still too late in coming. If Hegel saw Napoleon as the Zeitgeist on horseback, Baudelaire has no heroes except at times Satan and Lucifer. Bataille, as Caillois was to note, has only Satan; he has lost even Lucifer.

For what lacks in the modern world for Bataille is the sacred - not the sacred of organized religion, but a sacred having to do with ritual and communion. Until the late thirties, Bataille genuinely believed that the societies he created, secret and public, could reinstate a sense of the sacred and of community in modern life. With the war, and with the beginnings of his illness however, he becomes disillusioned. Modernity is such that everyday life cannot be resacralized. Whereas Benjamin will posit shock as the recognition of the aura's demise under modernity, Bataille chooses to express the loss through the more violent juxtaposition of willed and simultaneous "now's"; of the incompatible. Roger Caillois called this Bataille's will to tragedy (Nietzschean allusion intended), and in this Callois agreed with Sartre's assessment.

Bataille's quest for community, for that which puts the subject itself at risk, for rupture these are aspects of a new thought for Sartre. He understands such thought as a sneaky reinscription of Aufhebung, and rejects it as such. The apparent ease with which Sartre rejects Inner Experience may in fact betray, in light of his subsequent work, a temptation toward the very transcendent tendencies of which he accuses Bataille. To reject the Aufhebung, after all, is a different proposition. In any case, Sartre will maintain (to the end of his life) an ardent belief in human freedom, in the usefulness of language, in human choice, responsibility, and singularity. "Un nouveau mystique," then, may be seen as a seminal text marking the fork in the road between modernism and its heir: a postmodernism impatient with any sovereign subject and suspicious if not dismissive of any notion of human freedom. 


\section{References}

Barthes, Roland (1977), Writing Degree Zero. Trans. Annette Lavers and Colin Smith. New York: Hill \& Wang, 1977 [1953].

Bataille, Georges (1957), "Baudelaire," La littérature et le mal. Paris: Gallimard. English trans. "A Perfect Silence of the Will," in Harold Bloom (ed.), Charles Baudelaire: Modern Critical Views. New York: Chelsea House, 1987.

Bataille, Georges (1983), Manet. Genève: Skira.

Bataille, Georges (1985), Visions of Excess: Selected Writings, 1927-39. Edited, translated and with an introduction by Allan Stoekl. Minneapolis: University of Minnesota Press.

Bataille, Georges (1987), "A Perfect Silence of the Will," in Harold Bloom (ed.), Charles Baudelaire: Modern Critical Views. New York: Chelsea House.

Baudelaire, Charles (1968), Baudelaire: Oeuvres complètes. Ed. Y.G. Le Dantec and Claude Pichois. Paris: Gallimard.

Derrida, Jacques (1978), "From Restricted to General Economy: A Hegelianism Without Reserve," Writing and Difference. Trans. Alan Bass. Chicago: University of Chicago Press.

Derrida, Jacques (1982), "Ousia and Gramme: Note on a Note from Being and Time," Margins of Philosophy. Trans. Alan Bass. Chicago: University of Chicago Press.

Goldstein, Jan (2005), "Of Marksmanship and Marx: Reflections on the Linguistic Construction of Class in Some Recent Historical Scholarship," Modern Intellectual History, 2(1), 87-107.

Heimonet, Jean-Michel (1996), "Bataille and Sartre: The Modernity of Mysticism," Diacritics, 26(2), 59-73.

Hollywood, Amy (2002), Sensible Ecstasy: Mysticism, Sexual Difference and the Demands of History. Chicago: University of Chicago Press.

Jay, Martin (2005), Songs of Experience: Modern American and European Variations on a Universal Theme. Berkeley: University of California Press.

Meltzer, Françoise (2002), "Rupture and the Limits of Reading," Romanic Review, 93(1-2).

Sartre, Jean-Paul (1946), Baudelaire. Paris: Gallimard.

Sartre, Jean-Paul (1947), “Un nouveau mystique," Situations I. Paris: Gallimard, 143-88.

Surya, Michel (2002), Georges Bataille: An Intellectual Biography. Trans. Krzysztof Fijalkowski and Michael Richardson. London/New York: Verso. 